\title{
Intellectual Capital: Perception of Public and Private Sector Knowledge-Based Organizations in Pakistan
}

\author{
Awais Alam Khan ${ }^{1}$, Dr. Waseef Jamal ${ }^{2}$
}

Abstract

Purpose - This paper explores the perception of public and private sector managers regarding intellectual capital in knowledge based organizations in Pakistan.

Design/methodology/approach - Due to the intangible nature of intellectual capital resources, a qualitative methodology is chosen to get in-depth perception from the managers. Ten interviews were conducted in public and private sector organizations chosen on the basis of knowledge organization criteria and senior managers were interviewed to get an in-depth understanding of the phenomenon. The data was coded in Atlas.ti and analyzed.

Findings - It was discovered that there are several themes related to the different components of intellectual capital, which are common within both types of organizations. However, several elements were also found whose importance is differs across the organizations. Overall, it was found that management of intellectual capital is more organized and systematic in the private organizations. However, understanding of intellectual capital is also increasing in the public sector managers.

Practical implications - The utilization of intellectual capital is increasing in both types of organizations however, more steps are needed at the strategic level to manage the intellectual capital resources within the organizations.

Key words - Intellectual capital, knowledge management, human capital, structural capital, relational capital

Paper type - Research paper

\section{Introduction}

In the last twenty years, throughout the world, there has been a growing interest in the understanding of the role that intellectual capital (IC) play in the working of all forms of organizations (public and private sectors). IC resources are all non-monetary and non-physical resources that are fully or partially controlled by the organizations and that create value for the organization. Molnar (2004), finds that $94 \%$ of the CEOs surveyed are in agreement that IC resources need to be managed and measured and similarly, more than half are of the opinion that it is one of the three

1 Assistant Professor, Institute of Management Sciences Peshawar

2 Assistant Professor, Institute of Management Sciences Peshawar 
most important challenges for the organizations. Many researchers (Henry, 2013; Lonnqvist \& Mettanen, 2005; Roos, Pike, \& Fernstrom, 2005) argue that IC is important for all forms of organizations (listed companies, non-profit organizations and public sector organizations) and conclude that IC is one of the most important factors which are creating value for organizations and therefore need the attention of the managers to be identified, measured and managed. The value creating role of IC becomes more important in the knowledge based organizations. A knowledge organization is one which acknowledges and values the IC that gives it a distinctive competitive advantage over rivals (Lim \& Dallimore, 2004). In such organizations, knowledge affects the performance of the organization (Osterland, 2001) and encourages a continuous learning process and engages actively in the management of the IC (Huseman \& Goodman, 1999). It is worth mentioning that Molnar (2004) has found misunderstanding among the managers in different organizations regarding the IC phenomenon. Similarly, Stewart (1997), argues that lack of understanding IC can lead towards destroying the value creation process in the organizations. It can be said that IC is a powerful concept in the organizations yet, it needs to be researched in order to understand it in the right context.

The private sector recognized the importance of IC earlier than the public sector in various parts of the world and paid attention to the value creation process by utilizing their IC. Authors (Bontis 1998; Sveiby, 1997), attribute the success of Microsoft, McKinsey and others companies to their effective IC resources and its utilization rather than their physical or monetary wealth.

The public sector throughout the world is also passing through critical times and specifically with the arrival of information and communication technologies (ICTs), such organizations are now under more scrutiny of the stakeholders regarding the resource utilization and provision of better services to citizens. Roos et al. (2005), state that public organizations are under pressure to create value and prudently manage themselves financially. Since the 1980s, in developed countries first and later in the developing countries too, a movement has started in the public sector regarding public sector reforms in order to meet the stakeholders' expectation. Collectively this process of bringing change in the public sector organizations is known as new public management (Hood, 1991; Hood \& Jackson, 1991). This process stresses on the adoption of successful practices from the private sector. Based on the role of IC in the value creation process in the private sector, the public sector too is taking initiatives in different countries to deal with the IC. Still, it is needed to find out that whether the IC phenomenon is perceived same in the different contexts of public and private sectors or there are differences in these two sectors on this topic. 
This research is an effort in this direction to explore: the perception of managers working in the knowledge based public and private sector organizations in Pakistan; composition of IC in their organizations; comparisons of the similarities and differences in the IC composition and management and the importance of various IC elements in the respective organizations.

The next section discusses the review of the existing literature, followed by the methodology section. Findings of the interviews along with discussion have been given in section 1.4 and section 1.5 contains the conclusion and limitations.

\section{Literature Review}

Teece (2000), argues that globalization has brought changes in the competitive horizons of the business and now intangibles, such as knowledge and its application are a source of competitive advantage rather than the traditional factors of land, labor and material. In fact, these intangibles constitute $80 \%$ of the wealth of the knowledge based organizations in some cases such as pharmaceutical and IT based companies. Intellectual Capital (IC) is first used as a term by Skandia in 1994 by producing a report on its various aspects of the IC along with the annual report (Nermien, 2003). Stewart (1997, p. x), defines IC as "intellectual material, knowledge, information, intellectual property and experience - that can be put to use to create wealth" and further states that it is the sum of everything everybody in a company knows that gives it competitive advantage. Roos and Roos (1997, p.415), recognize that "IC is the sum of hidden assets of the company and includes both what is in the heads of the organizational members and what is left in the company when they leave". Similarly, Edvinsson (1997, p. 366) asserts that, "it [IC] refers to the possession of knowledge, applied experience, organizational technology, customer relationships and professional skills that provide [an organization] with a competitive edge in the market". Sveiby (1997) states that the IC of an organization can be classified as a family of three entities: employee competence, internal structure and external structure. From the earlier discussion above we can infer that IC can be defined in different ways, however, in most cases, it includes: the knowledge and skills of employees, the culture and values of the organization, its immaterial properties, organizational infrastructure and its relationships (Lonnqvist \& Mettanen, 2005) that is, human capital, structural capital and customer capital (Bassi, 1997; Edvinsson \& Malone, 1997; Saint-Onge 1996).

Knowledge organization needs to manage its human, structural and relationship capital because these are factors of value creation (Bassi, 1997; Bontis, 2001; Marr, Gupta, Pike, \& Roos, 2003) and intangible assets add value to the organization. According to CIMA (2007), for value creation in an organization, understanding of intangibles is a must. Harrison and Sullivan (2000) also suggest that firms can create 
value from their IC such as: profit generation, strategic positioning, innovations, customer loyalty, cost reductions and improved productivity. Therefore, it is widely agreed by practitioners and theorists that IC is an important factor in attaining competitive advantage for an organization.

The IC view of organizations has evolved from the resource based view of the organizations (Prahalad \& Hamel, 1990). An extension of the RBV is knowledge based perspective of the competitive advantage (Grant, 1996; Nonaka \& Takeuchi, 1995), based on the assumption that, knowledge is the most important resource in complex dynamic environments (Drucker, 1993; Nonaka \& Takeuchi, 1995) and knowledge is seen as the core of wealth value creating activities. According to Roos, Bainbridge, and Jacobsen (2001), this concept was further developed by Edvinsson (1997), Roos \& Roos (1997), Chatzkel (2002), and Pike, Rylander, and Roos (2001), as the intellectual capital perspective of the firm. The IC perspective views the intangible assets (human, structural and relational capital), unique to a particular organization as the source of value creation. Similarly the IC approach also identifies, correlates, and visualizes the way these resources are deployed, transformed and utilized, thus providing a complete picture of how the organization attains competitive advantage or added value.

\subsection{Components of IC}

Different researchers have classified IC into three broader categories of; human capital, structural or organizational capital and relationship capital (Saint-Onge, 1996; Stewart, 1997; Sveiby, 1997). Sveiby argues that human capital (HC) is the most important component of IC as no organization is complete without its workers. Sveiby (1997) further suggests that HC is the competence of the workers and it is based on the experience, education, and trainings. $\mathrm{HC}$ refers to all of the resources that are related with the workers of the organization and can be applied by the organization in its value creation process and it is composed of the competence, attitude and intellectual agility (Roos et al., 2005). They elaborate competence as specific knowledge fields that encompass the tacit aspects, brain power, empathy, ability to build personal networks, and ability to participate in personal networks. Similarly, the attitude encompasses behavioral traits including social intelligence, motivation, sense of urgency and perseverance. While, intellectual ability has been referred to as the ability to innovate, imitate and adapt (Tovstiga \& Tulugurova, 2009). HC is important as it is a source of innovation and strategic renewal (Bontis, 1998; Stewart, 1997). HC is the tacit knowledge embedded in the minds of employees; it is the combined intelligence, skills and expertise, giving organizations distinctive character (Bontis, 1999). Talented and competent employees are the main ingredient of value 
creation in the organizations and despite the advancements in the ICTs, even now the decision making is with the workforce of the organizations meaning that all efficiency and effectiveness in the organization can be brought by the employees only (Johnson, Manyika, \& Yee, 2005). Stiles \& Kulvisaechana (2003) also argue that HC advantage depends on securing exceptional talent, or, in the familiar phrase, 'the best and the brightest' employees.

From the above discussion it can be concluded that the $\mathrm{HC}$ component of organization is its most important component. However in order to utilize this $\mathrm{HC}$, the organizations also need to develop systems and structures to get maximum benefit from the HC. For this, purpose the effective utilization of structural capital is needed (Henry, 2013).

Sullivan (2000) view structural capital (SC) as the support or infrastructure that an organization provides for its HC. This support can be in the form of physical elements such as; computers, desks, and offices or intangible aspects such as; information systems, software, standard operating procedures and manuals etc. (Stewart, 1997). Similarly, providing facilities in the workplace, organizational culture and presence of the strategic plans, vision, mission and cost structures and other elements are also considered as the part of the SC (Roos et al., 2005; Sveiby 1997). Bontis, Keow, and Richardson (2000), argue that poor SC hampers the utilization of the HC and therefore establishing a proper SC can help in enhancing the value creation process of the organizations. Stewart (2001) has given the examples of British Petroleum and World Bank, that by establishing knowledge management systems in their organizations, they were able to become more efficient and effective. Stewart (1997) further adds that SC should serve two purposes in the firms. One, to codify the knowledge and the other is to provide the codified knowledge to the workers, as and when required. The SC also influences the element of integration within the organizational design of the firms (Henry, 2013). Although there is no single organizational structure to point out that suite all types of organizations, however, it is important that the structure of organization should be such that it provides the channels of communication that will maximize the efficiency and creativity of the HC (Kim \& Kumar, 2009). The management philosophy of an organization is also a very important element of its SC. It is viewed as the set of beliefs used by the managers in the decision making process and it is considered as an important part of the SC (Henry, 2013). Similarly, Bontis (2001) adds that organizational with strong SC will have a supportive culture which will enable the $\mathrm{HC}$ of the organization to continuously innovate and learn and thus would help the organizations in the value creation process. The concept of quality management is also very important element of the SC. Tseng and Goo (2005) have associated the reputation of organization with the quality of their products and ser- 
vices. Nowadays, organizations are following international standards. The presence of such systems is also considered as the part of the SC. A special aspect of SC is social capital (Karp, 2003; Lengnick \& Legnick, 2003; Moran \& Ghoshal, 1996; Nahapiet \& Ghoshal, 1998), which facilitates the development of IC by providing the necessary conditions for exchange and combination of knowledge. The ability to create social capital is dependent on the infrastructure but more importantly, on the culture and climate of the organization which are the different elements of the SC.

The third component of IC is the relational or customer capital or external capital (used inter-changeably) [Sveiby 1997; Stewart 1997; Sullivan, 2000]. Saint-Onge (1998, p. 2) defines it as "the depth (penetration), width (coverage), and profitability of the organization's franchise”. Bontis (1999) explains that knowledge of market channels, customers/stakeholders and suppliers relationships, as well as a sound understanding of governmental or industry association impacts, is the main theme of relationship capital (RC). In this era of information, relationships are becoming more important for businesses be that is with the customers, suppliers or governments. Such relationships enable the organizations to become aware of the customer, market, and associates needs and then they can utilize their $\mathrm{HC}$ and SC to fulfill those requirements in a better way. Kianto, Hurmelinna-Laukkanen, and Ritala. (2010) refer $\mathrm{RC}$ to the ability of the firms to positively interact with the stakeholders in order to create value. $\mathrm{RC}$ is also considered with the acquisition and sharing of knowledge from the various components of the value chain of the organization and the more an organization is able to develop sound relationships with its associates the better it is for the value creation. Kale, Singh, and Perlmutter (2000) suggest that stronger relationship between the network member results in greater network learning thus synergizing the overall value network.

The review of literature on IC has shown that IC is composed of various components and the components of IC i.e. HC, SC and RC are essential for the value creation, regardless of the organizational type and these components are contributing towards the value creation.

\subsection{IC and the Pharmaceutical Industry}

Various researches have been conducted on IC its components and impact on the pharmaceutical industries. This industry has all of the characteristics of knowledge based organizations and Nakamura (2001) reports that US companies invest around $\$ 1$ Trillion per year in intangibles, which shows a huge investment. However, most of the pharmaceutical companies are not able to identify their IC and even if identified, they are not properly handling such resources. Similarly as in the other cases the intellectual property and structural capital are usually reported by the pharmaceutical 
companies however, the human capital or relational capital is ignored. Therefore, further research is required on incorporation of these IC resources into the books of the companies (Boekestein, 2006). Daum (2005) concludes that pharmaceutical industry is a great source of IC, since this industry is research-intensive, highly innovative and well balanced in its use of human capital and technological knowledge (Hermans, 2004). Pharma industry is extensively dependent on its IC as a key source for innovation. Similarly, Kamath (2008) investigates the relationship between the components of IC and its impact on the corporate performance of the Indian pharmaceutical industries and concludes that human capital has positive impact on the corporate performance of the Indian pharmaceutical industries. However, weaker relations were found between the other components of the firms in that research. Sharabati, Jawad, and Bontis (2010), report that IC components are playing very important role in the value creation process in the pharmaceutical sector in Jordan and senior managers are paying proper attention to its management as well. As discussed earlier too, it is not just the identification of these resources but their proper management is also needed to properly utilize these resources in the value creation process. Mehralian, Rajabzadeh, Sadeh, and Reza (2012) empirically tested the IC components with the traditional measures of performance (profitability, productivity, and market valuation). Their results show that the relationships between the performance of a company's IC and conventional performance indicators are varied. The findings suggest that the performance of a company's IC can explain profitability but not productivity and market valuation in Iran. Hess and Rothaermel (2011) analyzed 108 global pharmaceutical companies over three decades (1974-2003) and concluded that recruitment and retention of competent human capital and their engagement in strategic alliances are necessary assets for innovative performance. The empirical study to investigate the effect of intangible asset on innovation in Taiwanese biopharmaceutical industry shows that intellectual resources positively affects innovation process, and the organization capital mediates the relationship between intangible assets (IC) and innovative capability in this industry (Huang, 2011). In another study, Cheng, Lin, Hsiao, and Lin (2010), argue that there is a significant relationship between IC and company performance in US healthcare industry. These results also suggest that innovative capacity and process reformation shall be considered first, and through the human value-added of human capital, firms can improve their company's performance.

\subsection{IC and Public Sector}

Just like the business organizations which are always looking for enhancing their value creation, public organizations all over the world are also continuously facing pressures from society to increase their effectiveness and service quality with available resources (McAdam \& Reid, 2001; Riege \& Lindsay, 2006). Similarly, it is 
acknowledged that public sector organizations need to change their way of thinking and acting and move from rigid bureaucratic structures towards more entrepreneurial ones, to increase productivity and service quality (Accenture, 2004; Sotirakou \& Zeppou, 2004).

Keeping in view the changing scenario, several efforts were undertaken in different countries in the 1980s and 1990s directed towards modernizing the public sector, and towards bringing new thinking and processes into the public sector to make them more efficient and more responsive to customers (Bovaird \& Loffler, 2003). Several management practices such as total quality management, business process reengineering and balanced scorecard (McAdam \& Reid, 2001) have been applied from the business world to the public sector, to redefine the organization, strategy, measure progress and outcomes, efficiently and effectively to the satisfaction of all stakeholders (Sotirakou \& Zeppou, 2004). Mouritsen, Thorbjornsen, Bukh, and Johansen (2004) regard IC and IC statements as an attempt to bring change in the public sector, as they conclude that IC helped the public sector in Denmark to become more strategic, independent and performance oriented, as it helps in internal management by learning how to develop and operate a more distributed system of management. Wiig (2002) also suggests that public sector's quality and effectiveness are influenced by different factors, such as, organizational structures, information, and experience of employees which are all the different elements of the IC components. Similarly, Sotirakou and Zeppou (2004) also argue that public sector modernization cannot work without the involvement and commitment of its human capital and thus IC is the most critical and valuable asset in developing a new management style in public sector organizations.

Furthering the concepts of components of IC in public sector performance enhancement, Australian Government Information Management Office (AGIMO, 2006) reports that the structural capital i.e. ICTs is transforming the way government operates and the pace of change is increasing over time. ICT advances can provide better service delivery, improve efficiency and reduce costs.

Researchers (Cinca, Molinero, \& Queiroz, 2003; Ramirez, 2010) explore the study of IC in public sector and conclude that this topic still needs further attention as it is utilizing more intangible resources such as $\mathrm{HC}$ and knowledge as compared to other type of organizations and therefore needed more systematic approach towards the identification, measurement and management of the IC and the existing business sectors' IC measurement and management tools are not entirely applicable in the it. Wall (2005) asserts a different opinion of the better management of IC in the public sector, as governments, especially in the UK, since 1979 have emphasized on performance measurement and the achievements of pre-determined targets but still much 
more efforts are needed to manage all aspects of IC management.

Cinca et al. (2003) also categorize the components of IC into four different components of internal organization, external structural capital, human capital and social and environmental commitment. Abeysekera, Jebeile, Kamuruddin (2010) also adds reputation along with the performance as the outcome of IC management in the public sector. McAdam and Reid (2001) argue that due to the success of IC in the corporate sector the time is now ripe for the public sector to adopt this management practice too.

It can be concluded from the literature discussed above that IC has affected all sectors of the knowledge economy and the traditional bureaucratic structures impede service delivery. Similarly the provision of services to the public in this current era can be improved by the efficient utilization of the three components of the IC through empowerment, technology, accountability and improved relationships.

This research further explores the perception of managers in public and private sector regarding the IC, its different components, its management and its role in their organizations.

\section{Methodology}

This research in consistency with Yoshikawa, Weisner, Kalil, and Way (2008) is using qualitative research techniques. Organizations that are chosen for this research are knowledge based organizations (Lim \& Dallimore, 2004), which are utilizing the various elements of IC for value creation. Pharmaceutical industries have all the characteristics of knowledge organizations i.e. they are involved in the knowledge management activities, they need to develop distinctive structural capabilities to remain competitive and they need to maintain relations with different stakeholders to create value (Boekestein, 2006). Similarly, public sector organizations though different from the pharmaceutical industry, however, are selected on the basis of similarities, in the utilization of IC (human, structural and organizational capital).

Different researchers (Bontis, 2001; Kannan \& Aulbar, 2004; Martins \& Dos Reis, 2010, Petty \& Guthrie 2000) are of the view that IC as an area of research is very difficult to define and quantify and therefore an exploratory approach is more appropriate to get an in-depth knowledge of the theoretical and practical implications of the phenomenon under-study. Hedlund (1994) also, asserts adopting a qualitative methodology in the research which involves tacit/intangible context. A qualitative methodology was therefore chosen as it allows the flexibility to investigate IC in the target organizations in more details and to explore the ideas of interest that may have developed during the data collecting process. The selection of a qualitative approach 
allows the researchers to get close to participants and their thinking in order to scrutinize the entire research problem (Maykut \& Morehouse, 1994). Thus, the focus remains on understanding people's words and behavior (Creswell, 2003).

For this research, one national level pharmaceutical company and one public sector organization (which is related with the revenue collection) was chosen (based on the knowledge criteria). The selected organizations were contacted by personal visits and given an explanation on the nature of study, the data to be collected, method of collection, and to seek their willingness to participate in the process. Due to this explanation, all organizations approached indicated that they would be willing to be involved and ten interviews were conducted in person on the premises of the respondents.

In both organizations, the respondents were given an explanation of some of the common terms and phrases that were going to be used in the interview. They were also given the opportunity to ask questions to clarify any terminology or concerns that they may have. For this interview, the respondents were selected who may have had at least worked in the organization from 9-20 years and thus had a huge experience in the organization and could have easily understand the concepts and practicalities of their organizations, plus they could have easily talked about the strategic level input of IC in their organizations. The respondents are having at least post-graduate level education with some of them having multiple degrees and trainings inside the country and abroad.

Table 1 presents the general profiles of the respondents interviewed, along with their education and years of experience in their organizations. The names of the

Table 1: Profile of the Respondents

\begin{tabular}{|l|l|l|l|l|}
\hline ID & Respondent Position & $\begin{array}{l}\text { Organization } \\
\text { Type }\end{array}$ & Education & Experience \\
\hline PS1 & Middle Management & Public Sector & Post-graduation & 10 Years \\
\hline PS2 & Middle Management & Public Sector & Post-graduation & 12 Years \\
\hline PS3 & Department Head & Public Sector & Post-graduation & 14 Years \\
\hline PS4 & Middle Management & Public Sector & Post-graduation & 10 Years \\
\hline PS5 & Middle Management & Public Sector & Post-graduation & 13 Years \\
\hline PrS6 & CEO & Private Sector & Post-graduation & 19 Years \\
\hline PrS7 & Department Head & Private Sector & Post-graduation & 12 Years \\
\hline PrS8 & Department Head & Private Sector & Post-graduation & 12 Years \\
\hline PrS9 & Middle Management & Private Sector & Post-graduation & 9 Years \\
\hline PrS10 & Top Management & Private Sector & Post-graduation & 13 Years \\
\hline
\end{tabular}


organizations and respondents have been kept confidential, based on their requests.

Semi-structured interviewed were used to collect data from the respondents. The interviews were recorded and later transcribed, in consistence with Grindsted (2005). The responses were then coded into Atlas.ti software and analyzed. Semi-structured interview technique was used, as it can result in more consistency and comparability in the responses from the data collected. Attride-Stirling (2001) analytical approach was adopted which emphasizes on the extraction of basic themes, which is then grouped into organizing themes and later into global themes. While in this particular research, the global theme was already known i.e. IC, the purpose was to explore the textual data for the basic and organizing themes in both organizations in their specific context.

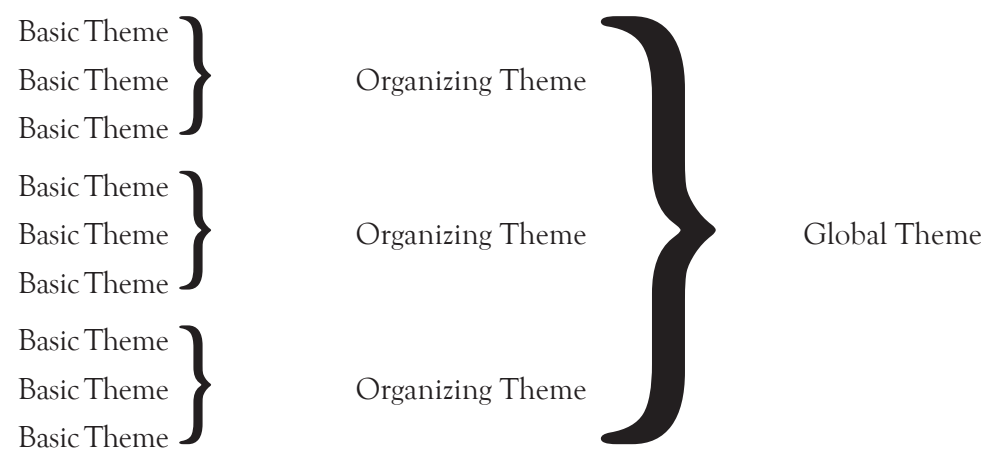

Figure 1: Scheme of Thematic Network (Attride-Stirling, 2001)

The interviews were anonymized for confidentiality; therefore data relating to the names of organizations was omitted from the work. This is also in keeping with the (Chell, 2004), ethical practice in the researching process.

\section{Findings and Discussions}

The findings presented here show the perception of the managers in both public and private organizations regarding the IC and its various aspects, as experienced by them in their organizations.

Regarding defining the IC as a phenomenon and its role in value creation, a general understanding of IC was found in the interviews of all of the respondents which is a very encouraging perspective. This means that IC is acknowledged as a source of competitive advantage and value creation in both sectors of the country. As one of the respondent (PS3) who was heading the human resources department, from the public sector commented:

"IC is the most important consideration for providing improved services to our customers and without investing in IC we could have never reached to the position 
where we are now".

Similarly, the private sector respondent who was the CEO (PrS6) of the organization, defines it as,

"IC is the collective knowledge of all individuals working in an organization that can be utilized for growth of the organization".

Both of the statements are encouraging in a sense that IC is acknowledged as source of value creation in the organizations and the first step towards the management of IC is its recognition. Throughout the world, IC researchers have faced problems in visualizing it (Stewart 1997; Sveiby 1997; Bontis 1998) and therefore we are of the opinion that there is a positive trend in organizations, regardless of their type in Pakistan.

The interviews unearthed some interesting and insightful concepts regarding IC in these organizations as well. Table 2, presents the general ideas and key words that emerged for each of the IC component from the interviews and for this purpose the general categorization of IC resources by Lee and Guthrie (2010) was used to allocate the individual elements to the various IC components.

Table 2: Elements of Intellectual Capital

\begin{tabular}{|l|l|l|}
\hline Human Capital & Structural Capital & Relational Capital \\
\hline Experience & Good working environment & E-environment \\
\hline Education & Air-conditioned offices & $\begin{array}{l}\text { Communication through } \\
\text { internet }\end{array}$ \\
\hline Trainings & Clean offices & Facilitation centers \\
\hline Capacity building & Paperless environment & $\begin{array}{l}\text { Grievances to the top manage- } \\
\text { ment }\end{array}$ \\
\hline Refresher courses & Website & New software to aid customers \\
\hline Salaries & e-business & $\begin{array}{l}\text { Information and education of } \\
\text { customers }\end{array}$ \\
\hline Motivation & ICTs & Fear in the mind of customers \\
\hline Knowledge management & Establishment of new offices & $\begin{array}{l}\text { Feedback mechanism from } \\
\text { customers }\end{array}$ \\
\hline Performance management & Strategic planning & Customer satisfaction \\
\hline On-job trainings & Quality Management Systems & Market surveys \\
\hline & SOPs & Affordable prices \\
\hline & cGMP & CSR \\
\hline & Expansion in facilities & \\
\hline & Automation & \\
\hline
\end{tabular}


The general themes that emerged from the different interview are in coherence with the IC literature and are again verifying that both types of organizations understand the concepts of the IC and its composition and are focusing their attention towards the importance of these resources. As discussed earlier too, in the knowledge economy, the competitive landscape is changing and it is moving from the tangible factors towards intangible factors (Drucker, 1993; Grant, 1996; Edvinsson \& Malone, 1997), therefore these themes obtained from the interviews verify the same trend in this part of the world too.

The diagrams below are the pictorial representations of the general themes that emerged for each component of the IC during the interviews.

Within the construct of human capital, education, training, experience, and knowledge management emerged as the key themes. This is in coherence with Edvinsson and Malone (1997) and Sveiby (1997), followed by remuneration and benefits and performance management, motivation, and refresher trainings. In both types of

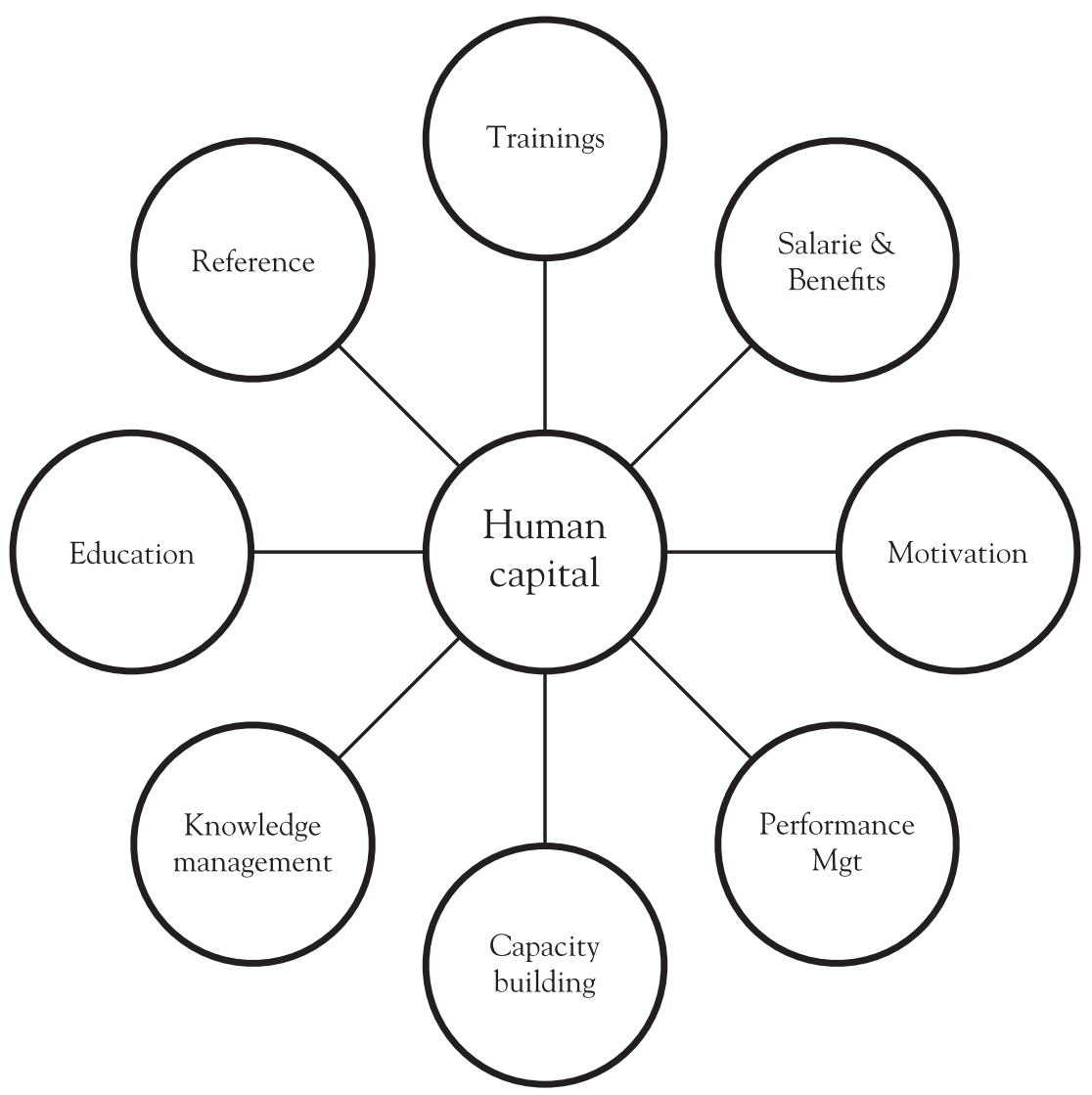

Figure 2: Human Capital Component 
organizations, employees are encouraged to enhance their levels of education at all levels and to the extent that employees are being given study leaves, and their education is being financed by the organizations. Similarly, trainings are also considered very important and in this regard various avenues are being utilized by the organizations under-study. The public sector organization in this case arranges trainings and refreshers for its different cadre of employees in-house as well as arranges foreign training programs, in the case of the private organizations; they too arrange in-house trainings as well as foreign trainers or abroad trainings, as and when required. The employees in the public sector have got more opportunities in the last 7-8 years, because of the reform process within the organization, which is very encouraging. One very important motivating factor in case of public sector employees was the double salaries, as compared with the rest of the public sector and employees are highly motivated in the organization because of this factor, perhaps we can conclude that by offering higher packages, public sector can be motivated to acquire and retain talented employees, which is the most important component of IC (Bontis, 1998; Stewart, 1997; Sveiby, 1997). Knowledge management activities are more practiced in the private sector and they have developed on-job trainings and knowledge management systems (KMS) as well. In public sector though, the tacit knowledge is transferred through on-job trainings, however, they have not yet been able to organize it in more systematic way, such as integration of knowledge sharing and performance of the employees. The presence of a performance management system play a huge role in enhancing the efficiency and effectiveness of the organizations (Franco \& Bourne, 2003; Lonnqvist \& Mettanen, 2005) and even in the public sector it was noted that the performance is now managed through multiple perspectives such as key performance indicators, and performance evaluation reporting, which is step in better direction. The private sector in case was found to be having a more detailed performance management system, which is properly communicated to each employee of the organization and they are following a 360 degree approach.

The structural capital component of IC has also yielded positive and encouraging results in the current research. Specifically, in the public sector in this case, the conversion of office environment to the corporate style open settings, with climate control and ICT integration was mooted as a very positive step towards the overall improvement in the performance of the organization. Similarly, change in the business processes due to automation and introduction of e-business and websites are also considered as part of the structural capital (Cinca et al., 2003). The introduction of software for the facilitation of managers and customers has increased the productivity of the work-force. The availability of the standard operating procedures (SOPs), development of newer divisions for strategic planning, and movement of the organization towards the corporate culture from the typical bureaucratic culture 


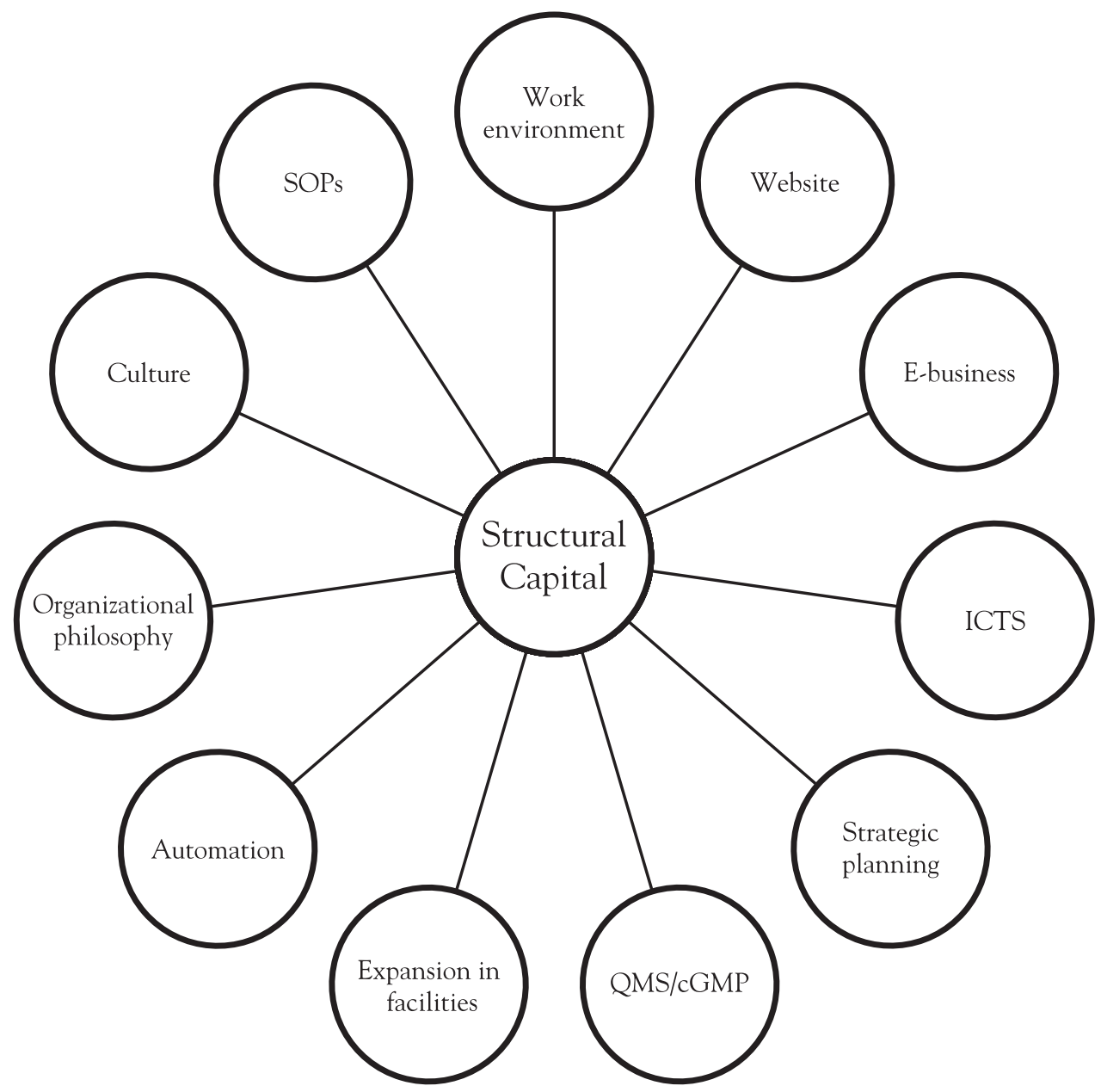

Figure 3: Structural Capital Component

are the important considerations within the organization. The interviews from the private sector added new elements of quality management systems (QMS), current good manufacturing practices (cGMP) and organizational philosophy to the structural capital of the organization (Hipp \& Grupp, 2005). The presence of such good practices contribute a lot to efficiency and effectiveness of the organizational operations apart from compliance with the rules and regulations and can help the organizations in attaining an edge over the competitors. Similarly, the organizations are noted to be expanding their structural resources in order to better cater to their operational and customer requirements. In the context of ICTs and e-business, both types of organizations understand the importance of these elements and are investing to strengthen these elements. However, at current level, it was found that organizations in private sector are creating more 'value for money' from their ICT resources as compared to 


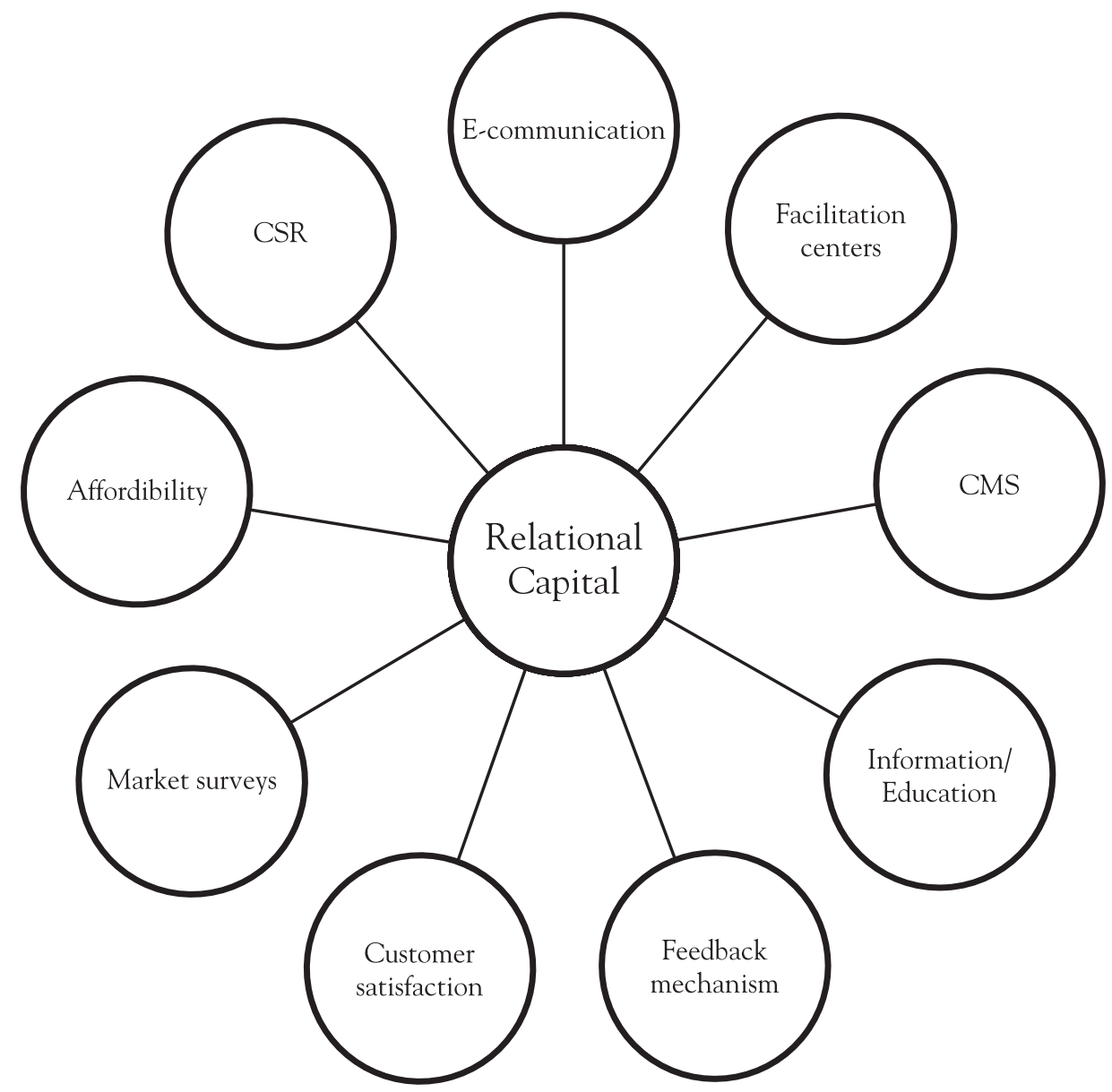

Figure 4: Components of Relational Capital

the public sector organization but a general realization was also found in the interviews of the public sector managers regarding the enhancement of the role of ICTs in their organizations.

The interviews revealed different key words in the relational component of IC from the organizations studied and again there was a positive trend found that regardless of the organization's type, relationships with different stakeholders are now considered more important. This specifically is more important in the public sector, where earlier there was no concept of the 'customer' and term 'applicant' was in common use. So there have been changes in the context of 'customer orientation' of organization and from the interviews with the managers in public sector it can be deducted that they are continuously bringing changes in their services, by becoming more interactive and communicating with customers through the internet and emails. Senior managers are now meeting, listening and handling the complaints/ 
grievances of the customers. Similarly, customers are being facilitated at dedicated facilitation offices/desks and are provided information and training regarding new services/procedures of the organization. The customer complaints handling process is become more stringent and it is also part of the performance management system. The private sector is also well-cognizant with the importance of the relational capital and is additionally doing market surveys to better know about the customer needs, have developed customer feedback mechanisms as integrated part of their quality management and customer satisfaction as part of their organizational mission. The managers over there are taking the relational capital as a holistic concept and encompass all aspects of the $\mathrm{RC}$ including relationship with customers, business partners and government and communities (McAdam \& Reid, 2001). They are also incorporating affordable pricing and corporate social responsibilities too in their RC, though the public sector managers did not discussed the social responsibilities which is showing difference from Cinca et al. (2003) findings.

Both set of managers' interviews were also compared for the most common and contrasting views on the IC components and various elements of those components. Table 3 shows the most common and contrasting themes along with relative importance in each type of managers' set.

The common and contrasting themes further tell us about the facts that human capital has become more important for the organizations over a period of time. One aspect of $\mathrm{HC}$ is with the motivation of $\mathrm{HC}$ to utilize its experience and skills for value creation in the organizations and in this case, the remuneration is playing huge role in the public organization while in the private organization money is not the major factor for this motivation. One probable reason can be that private sector acquires the talent on competitive salaries and their remuneration is market based. Similarly, structural capital is getting importance in both sectors and specifically, the physical expansion and expansion in SC is happening in both types of organizations, however, knowledge sharing activities are more common in the private managers as compared with the public managers. One reason of this phenomenon is the integration of knowledge sharing activities with the remuneration in the private organization understudy. At the same time the public sector has relatively strong SC as compared with the private. The relational capital is again having more strength in the private sector as it is ingrained in their QMS systems and organizational philosophy. On the other side, the public sector is still moving in that direction but has still way to go.

\section{Conclusion}

Based on the analysis of the data collected it can be inferred that IC is becoming an important consideration of value creation in organizations in Pakistan. Regardless 
Table 3: Common and contrasting themes in public and private sector managers perception

\begin{tabular}{|c|c|c|c|c|c|}
\hline $\begin{array}{l}\text { Common } \\
\text { themes }\end{array}$ & $\begin{array}{l}\text { Relative } \\
\text { importance }\end{array}$ & $\begin{array}{l}\text { Public sector } \\
\text { themes }\end{array}$ & $\begin{array}{l}\text { Relative } \\
\text { importance }\end{array}$ & $\begin{array}{l}\text { Private sector } \\
\text { themes }\end{array}$ & $\begin{array}{l}\text { Relative } \\
\text { importance }\end{array}$ \\
\hline Education & $* * *$ & Education & $* * *$ & Education & $* * *$ \\
\hline Trainings & $* * *$ & Experience & $* * *$ & Training & $* * *$ \\
\hline Experience & $* * *$ & Salaries & $* * *$ & $\begin{array}{l}\text { Knowledge } \\
\text { sharing }\end{array}$ & $* * *$ \\
\hline $\begin{array}{l}\text { Knowledge } \\
\text { management }\end{array}$ & * & Trainings & $* * *$ & PMS & $* * *$ \\
\hline $\begin{array}{l}\text { Performance } \\
\text { management }\end{array}$ & $* * *$ & Performance Mgt & $* * *$ & QMS & $* * *$ \\
\hline $\begin{array}{l}\text { On-job train- } \\
\text { ings }\end{array}$ & ** & $\begin{array}{l}\text { Work environ- } \\
\text { ment }\end{array}$ & $* * *$ & ICTs & $* * *$ \\
\hline $\begin{array}{l}\text { Work environ- } \\
\text { ment }\end{array}$ & $* * *$ & ICTs & $* *$ & $\begin{array}{l}\text { Work environ- } \\
\text { ment }\end{array}$ & $* * *$ \\
\hline ICTs & ** & Strategic planning & $* * *$ & $\begin{array}{l}\text { Organizational } \\
\text { philosophy }\end{array}$ & *** \\
\hline $\begin{array}{l}\text { Strategic Plan- } \\
\text { ning }\end{array}$ & $* * *$ & Expansion & $* * *$ & Expansion & $* *$ \\
\hline Expansion & $* * *$ & SOPs & $* * *$ & $\begin{array}{l}\text { Customer } \\
\text { satisfaction }\end{array}$ & $* * *$ \\
\hline $\begin{array}{l}\text { Organizational } \\
\text { culture }\end{array}$ & $* *$ & Culture & $* *$ & Market surveys & $* *$ \\
\hline SOPs & $* * *$ & CMS & ** & CSR & ** \\
\hline $\begin{array}{l}\text { Complaints } \\
\text { Management }\end{array}$ & ** & & & & \\
\hline $\begin{array}{l}\text { Feedback } \\
\text { mechanism }\end{array}$ & ** & & & & \\
\hline
\end{tabular}

Where

$* * *=$ Most important

$* *=$ Important

*= Less important

of the type of organization, the intellectual resources are gaining importance in managers' perception (Stewart, 1997; Sveiby, 1997; Edvinsson \& Malone, 1997). Similarly, most of the managers believe that IC is composed of the different components of human, structural and relational capital and then it has different elements within each component. This adheres with the Mouritsen (2006), regarding the idiosyncratic nature of IC in different contexts. This view has gained momentum in the recent 
IC research as well (Dumay, 2009; Dumay \& Garanina, 2013; Guthrie, Ricceri, \& Dumay, 2012; Roslender \& Stevenson, 2009). The two types of organizations have some differences when it comes to the issue of measurement and management of intellectual resources, specifically in public sector, despite the fact that IC is used to the great extent, however, its importance, identification, measurement and management still requires a lot of efforts, this is in consistency with (Wall, 2005). The position in private organizations is comparatively better as they are more focused on the efficiency and effectiveness, however, the public sector too, because of increasing pressures from the stakeholders are developing and reforming themselves to manage their intellectual resources in a better way. In this regard, strategic management is urged at the strategy level in order to develop proper strategies to manage their intellectual capital (Marr \& Chatzkel, 2004; Dumay, 2009). However, based on the data collected, it can be inferred that by and large, there is some common consensus on the management of intellectual resources in the organizations. Still, there are differences in the nature of work of both type of organizations and therefore their consideration of importance differs in some aspects of the different elements of the IC components.

There are two main limitations of this study as well, one, the sample size was small and second, the interviews were confined to the respondents working in two organizations. The inferences drawn from the analysis and the conclusions made should therefore be treated as indicative rather than definitive. However, despite these limitations this study has contributed to the debate about understanding the perceptions of the managers in both sectors. An empirical study is also needed to find out the relative proportions of the different components of IC in these sectors.

\section{References}

Abeysekera, I., Jebeile, S. \& Kamuruddin, K. (2010). Researching for intellectual capital management in new public sector organisations for effectiveness, efficiency, and reputation. AFAANZ Conference 2010 (pp. 1-23). Christchurch, New Zealand: AFAANZ.

Accenture (2004). 2004 E-Government Report: High Performance, Maximum Value. [Online]. Retrieved from: http://www.accenture.com/Global/Research_and_Insights/By_Industry/Government/default. htm.

AGIMO (2006). 2006 E-Government Strategy. [Online]. Retrieved from: http://www.finance.gov.au/ publications/2006-e-government-strategy/docs/e-gov_strategy.pdf

Attride-Stirling, J. (2001). Thematic networks: An analytic tool for qualitative research. Qualitative Research, 1(3), 385-405.

Bassi, L. J (1997). Harnessing the power of intellectual capital. Training and Development, 51 (12), 25-30. 
Boekestein, B. (2006). The relation between intellectual capital and intangible assets of pharmaceutical companies. Journal of Intellectual Capital, 241-253.

Bontis, N. (1998). Intellectual capital: an exploratory study that develops measures and models. Management Decision, 36 (2), 63-76.

Bontis, N. (1999). Managing organisational knowledge by diagnosing intellectual capital: framing and advancing the state of field. International Journal of Technology Management, 18 (5/8), 433-462.

Bontis, N. (2001). Assessing knowledge assets: a review of the models used to measure intellectual capital. International Journal of Management Reviews, 3(1), 41-60.

Bontis, N., Keow, W. C. C., \& Richardson, S (2000). Intellectual capital and business performance in Malaysian industries. Journal of Intellectual Capital, 1 (1), 85-100.

Chatzkel, J. (2002). A conversation with Goran Roos. Journal of Intellectual Capital, 3(2), 96-117.

Chell, E. (2004). Critical incident technique, in Cassell, C. and Symon, G. (Eds), Essential Guide to Qualitative Methods in Organizational Research, Sage Publications, London, 45-60.

Cheng, M.Y., Lin, J.I., Hsiao, T. \& Lin, T.W. (2010). Invested resource, competitive intellectual capital, and corporate performance. Journal of Intellectual Capital, 11 (4), 433-50.

CIMA. (2007). Understanding Corporate Value: Managing and Reporting Intellectual Capital. [Online]. Retrieved from:http://www.cimaglobal.com/cps/rde/xbcr/SID-OAAAC564 843E2805/live/ MgRptIntCap_techrpt_2003.pdf .

Cinca, C. S., Molinero, C. M., \& Queiroz, A. B. (2003). The measurement of intangible assets in public sector using scaling techniques. Journal of Intellectual Capital, 4(2), 249-275.

Creswell, J.W. (2003), Research Design. Qualitative, Quantitative and Mixed Methods Approaches, 2nd ed., Sage, Thousand Oaks, CA.

Daum, J.H. (2005). Intangible assets-based enterprise management: a practical approach. Proceedings of 2005 PMA IC Symposium, Stern School of Business, New York University, Manhattan, 15 December.

Drucker, P.F. (1993). The rise of the knowledge society. Wilson Quarterly, 17 (2), 52-70.

Dumay, J, \& Garanina, T. (2013). Intellectual capital research: a critical examination of the third stage. Journal of Intellectual Capital, 14 (1), 10 - 25.

Dumay, J.C. (2009). Reflective discourse about Intellectual capital: Research and practice. Journal of Intellectual Capital, 10 (4), 489-503.

Edvinsson, L. (1997). Developing intellectual capital at Skandia. Long Range Planning, 30 (3) 366-73. Edvinsson, L. \& Malone, M. (1997). Intellectual capital: Realising your Company's True Value by Finding its Hidden Brainpower, Harper Collins, New York, NY. 
Franco, M. \& Bourne, M (2003). Factors that play a role in managing through measures. Management Decision, 41 (8), 698-710.

Grant, R. (1996). Toward a knowledge-based theory of the firm. Strategic Management Journal, Vol. 17, 109-22.

Grindsted, A. (2005). Interactive resources used in semi-structured research interviewing. Journal of Pragmatics, 37 (7), 1015-1035.

Guthrie, J., Ricceri, F., \& Dumay, J. (2012). Reflections and projections: A decade of intellectual capital accounting research. The British Accounting Review, 44 (2), 68-82.

Harrison, S. \& Sullivan, P. H. (2000). Profiting from intellectual capital, learning from leading companies. Journal of Intellectual Capital, 1 (1), 33-46.

Hedlund, G. (1994). A model of knowledge management and the N-form corporation. Strategic Management Journal, 15 (S2), 73-90.

Henry, L. (2013). Intellectual capital in a recession: Evidence from UK SMEs. Journal of Intellectual Capital, 84-101.

Hermans, R. (2004). International Mega-Trends and Growth Prospects of the Finnish Biotechnology Industry. ETLA - The Research Institute of the Finnish Economy, Helsinki.

Hess, A.M. \& Rothaermel, F.T. (2011). When are assets complementary? Strategic Management Journal, Vol. 32, 895-909.

Hipp, C., \& Grupp, H. (2005). Innovation in the service sector: The demand for service-specific innovation measurement concepts and typologies. Research Policy, 34 (4), 517-35.

Hood, C. (1991). A public management for all seasons? Public Administration, Vol. 69, 3-19.

Hood, C., \& Jackson, M., (1991). Administrative Argument. Aldershot: Dartmouth.

Huang, H.C. (2011). Aligning intangible assets to innovation in biopharmaceutical industry. Expert Systems with Applications, Vol. 38, pp. 3827-3834.

Huseman, C. \& Goodman, J.P. (1999). Leading with knowledge: The nature of competition in the 21st century. Sage, Beverly Hills, CA.

Johnson, B. C., Manyika, J. M., \& Yee, L. A (2005). The next revolution in interactions. The McKinsey Quarterly, No. 14, 21-33.

Kale, P., Singh, H. \& Perlmutter, H (2000). Learning and protection of proprietary assets in strategic alliances: building relational capital. Strategic Management Journal, Vol. 21, Special Issue, 217-237.

Kamath, G. B. (2008). Intellectual capital and corporate performance in the Indian pharmaceutical industry. Journal of Intellectual Capital, 684-704. 
Kannan, G. and Aulbur, W.G. (2004). Intellectual capital: measurement effectiveness. Journal of Intellectual Capital, 5 (3), 389-403.

Karp, T (2003). Is intellectual capitalism the future wealth of organisation? Foresight, 5 (4), 20-27.

Kianto, A., Hurmelinna-Laukkanen, P. \& Ritala, P (2010). Intellectual capital in service and product oriented companies. Journal of Intellectual Capital, 11 (3), 305-325.

Kim, D. \& Kumar, V. (2009). A framework for prioritization of intellectual capital indicators in R \& D. Journal of Intellectual Capital, 10 (2), 277-293.

Lee L. L., \& Guthrie, J. (2010). Visualising and measuring intellectual capital in capital markets: a research method. Journal of Intellectual Capital, 11 (1), 4 - 22.

Lengnick-Hall, M. L., \& Lengnick-Hall, C. A (2003). HR's role in building relationship networks. Academy of Management Executive, 17(4), pp.53-66.

Lim, L. L., \& Dallimore, P. (2004). Intellectual capital: Management attitudes in service industries. Journal of Intellectual Capital, 181-194.

Lonnqvist, A \& Mettanen, P (2005). Criteria of Sound Intellectual Capital Measures, Business Performance Measurement: Intellectual Capital-Valuation Models. Le Magnus University Press, 97-120.

Marr, B., \& Chatzkel, J (2004). Intellectual capital at the crossroads: managing, measuring and reporting IC. Journal of Intellectual Capital, 5 (2), 224-229.

Marr, B., Gupta, O., Pike, S., \& Roos, G (2003). Intellectual capital and knowledge management effectiveness. Management Decision, 41 (8), 771-781.

Martins, A. \& Dos Reis, F.L. (2010). The model of intellectual capital approach on the human capital vision. Journal of Management Research, 2 (1), 1-20.

Maykut, P., \& Morehouse, R. (1994). Beginning Qualitative Research. A Philosophic and Practical Guide, The Falmer Press, London.

McAdam, R \& Reid, R (2001). SME and large organization perceptions of knowledge management: Comparisons and contrasts. Journal of Knowledge Management, 5 (3), 231 - 241.

Mehralian, G., Rajabzadeh, A., Sadeh, M. R., \& Reza, H. (2012). Intellectual capital and corproate performance in the Iranian pharmaceutical industry. Journal of Intellectual Capital, 138-158.

Molnar, M. J. (2004). Executive Views on Intangible Assets: Insights from Accenture/Economist Intelleigence Unit Survey. Accenture.

Moran, P. \& Ghoshal, S. (1996). Value Creation by Firms. In J.B. Keys \& L. N. Dosier (Eds.), Academy of Management Best Paper Proceedings, pp. 41-45.

Mouritsen, J. (2006). Problematising intellectual capital research: ostensive versus performative IC. Accounting, Auditing \& Accountability Journal, 19 (6), 820 - 841. 
Mouritsen, J., Thorbjornsen, S., Bukh, P.N., \& Johansen, M.R. (2004). Intellectual capital and new public management: re-inventing enterprise. The Learning Organisation, 11 (4/5), 380-392.

Nahapiet, J., \& Ghoshal, S. (1998). Social capital, intellectual capital, and the organisational advantage. The Academy of Management Review, 23 (2), 242-266.

Nakamura, L. (2001). Investing in Intangibles: Is a Trillion Dollars Missing from GDP? Business Review, 04, 27-37.

Nermien, A.-A. (2003). Comprehensive Intellectual Capital Management: Step by Step. New Jersey: John Wiley \& Sons.

Nonaka, I. \& Takeuchi, H. (1995). The knowledge-creating company. New York: Oxford University Press.

Osterland, A. (2001). Grey Matters: CFO's Third Annual Knowledge Capital Scorecard. CFO Magazine, Retrived from: http://ww2.cfo.com/strategy/2001/04/grey-matters-cfos-third-annual-knowledge-capital-scorecard/.

Petty, R., \& Guthrie, J. (2000). Intellectual capital literature review. Journal of Intellectual Capital, 1 (2), 155-76.

Pike, S., Rylander, A., \& Roos, G. (2001). Intellectual capital management and disclosure, in Bontis, N. and Choo, C.W. (Eds), The Strategic Management of Intellectual Capital and Organisational Knowledge - A Selection of Readings.

Prahalad, C.K., \& Hamel, G. (1990). The Core Competence of the Corporation. Harvard Business Review.

Riege, A. \& Lindsay, N (2006). Knowledge management in the public sector: stakeholder partnership in the public policy development. Journal of Knowledge Management, 10 (3), 24-39.

Roos, G., \& Roos, J. (1997). Measuring your company's intellectual performance. Long Range Planning, 30 (3), 413-426.

Roos, G., Bainbrige, A., \& Jacobsen, K (2001). Intellectual capital analysis as a strategic tool. Strategy and Leadership, 29 (4), 21-26.

Roos, G., Pike, S., \& Fernstrom, L. (2005). Managing Intellectual Capital in Practice. Oxford: Butterworth-Hheinemann.

Roslender, R., \& Stevenson, J. (2009). Accounting for people: A real step forward or more a case of wishing and hoping? Critical Perspectives on Accounting, 20 (7), 855-69.

Saint-Onge, H (1996). Tacit knowledge: The key to the strategic alignment of intellectual capital. Strategy and Leadership, 24 (2), 10-14.

Saint-Onge, H (1998). How knowledge management adds critical value to distribution channel management. Journal of Systemic Knowledge Management, Vol. 1. [Online]. Available from: http://www. 
tlainc.com/article1.htm. Accessed on 1 March 2014.

Sharabati, A.-A. A., Jawad, S. N., \& Bontis, N. (2010). Intellectual Capital and Business Perofrmance in the Pharmaceutical Sector of Jordan. Management Decision, 105-131.

Sotirakou, T. \& Zeppou, M. (2004). The "MATE" model: a strategic knowledge management technique on the chessboard of public sector modernisation. Management Decision, 42 (1), 69-88.

Stewart, T. A. (1997). Intellectual Capital: The New Wealth of Organizations. Nicholas Brealey, London. Stewart, T.A. (2001). Intellectual Capital: The Wealth of Knowledge. Currency Book, New York.

Stiles, P. \& Kulvisaechana, S (2003). Human capital and performance: A literature review. [Online]. Retrieved from: http://www.dti.gov.uk/files/file38844.pdf.

Sullivan, P. H. (2000). Value Driven Intellectual Capital: How to Convert Intangible Corporate Assets into Market Value: John Wiley \& Sons, Inc.

Sveiby, K. E. (1997). The New Organizational Wealth: Managing \& Measuring Knowledge-Based Assets. Berrett-Koehler Publishers, Inc., San Francisco.

Teece, D. J. (2000). Managing Intellectual Capital. New York: Oxford University Press.

Tovstiga, G. \& Tulugurova, E. (2009). Intellectual capital practices: A four region comparative study. Journal of Intellectual Capital, 10 (1), 70-80.

Tseng, C. \& Goo, Y.J. (2005). Intellectual capital and corporate value in an emerging economy: Empirical study of Taiwanese manufacturers. R\&D Management, 35 (2), 187-201.

Wall, A. (2005). The measurement and management of intellectual capital in the public sector. Public Mangement Review, 7 (2), 289-303.

Wiig, K. M. (2002). Knowledge Management in Public Administration. Journal of Knowledge Management, 6 (3), 24-239.

Yoshikawa, H., Weisner, T.S., Kalil, A. \& Way, N. (2008). Mixing qualitative and quantitative research in developmental science: Uses and methodological choices. Developmental Psychology, 44 (2), 344-354 . 